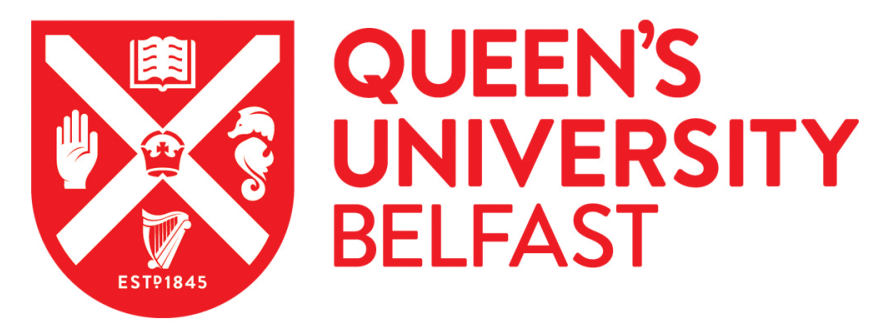

\title{
From gendered organizations to compassionate borderspaces: Reading corporeal ethics with Bracha Ettinger
}

Kenny, K., \& Fotaki, M. (2015). From gendered organizations to compassionate borderspaces: Reading corporeal ethics with Bracha Ettinger. Organization, 22(2), 183-199. https://doi.org/10.1177/1350508414558723

\section{Published in:}

Organization

\section{Document Version:}

Peer reviewed version

Queen's University Belfast - Research Portal:

Link to publication record in Queen's University Belfast Research Portal

Publisher rights

(c) The Author(s) 2014

Reprints and permissions: sagepub.co.uk/journalsPermissions.nav

\section{General rights}

Copyright for the publications made accessible via the Queen's University Belfast Research Portal is retained by the author(s) and / or other copyright owners and it is a condition of accessing these publications that users recognise and abide by the legal requirements associated with these rights.

Take down policy

The Research Portal is Queen's institutional repository that provides access to Queen's research output. Every effort has been made to ensure that content in the Research Portal does not infringe any person's rights, or applicable UK laws. If you discover content in the Research Portal that you believe breaches copyright or violates any law, please contact openaccess@qub.ac.uk. 
From gendered organizations to compassionate borderspaces: Reading corporeal ethics with Bracha Ettinger

\section{Kate Kenny and Marianna Fotaki}

Please reference as:

Kenny, K. \& Fotaki, M. (2015) From gendered organizations to compassionate borderspaces: Reading corporeal ethics with Bracha Ettinger. Organization 22(2): 183199.

The final, definitive version of this paper has been published in Organization by SAGE Publications Ltd, All rights reserved. (C) This is the accepted version, posted by the first author on the Queen's University Belfast website under the terms of the contributor agreement.

Accepted version, final publication:

http://org.sagepub.com/content/early/2014/12/02/1350508414558723.full.pdf 


\begin{abstract}
In this paper, we propose a new way of approaching the topic of ethics for management and organization theory. We build on recent developments within critical organization studies that focus on the question of what kind of ethics is possible in organizational contexts that are inevitably beset by difference. Addressing this 'ethics of difference', we propose a turn to feminist theory, in which the topic has long been debated but which has been underutilized in organization theory until very recently. Specifically, we draw on the work of Bracha Ettinger to re-think and extend existing understandings. Inspired by gender studies, psychoanalysis, philosophy and art, Ettinger's work has been celebrated for its revolutionary re-theorization of subjectivity. Drawing on a feminist ethics of the body inspired by psychoanalysis, she presents a concept of 'transsubjectivity'. In this, subjectivity is defined by connectedness, co-existence and compassion towards the other, and is grounded in what Ettinger terms the 'matrixial borderspace'. An ethics of organization derived from the concept of the matrixial suggests that a different kind of ethical relation with the Other is possible. In this paper, we demonstrate this through examining the issue of gender in the workplace. We conclude by outlining the implications of this perspective for rethinking ethics, embodiment and gender, and in particular for the development of a corporeal ethics for organization studies.
\end{abstract}

Keywords: ethics, embodiment, Ettinger, gender, matrixial, organization 


\section{Introduction}

The concepts of difference and otherness are central to organizational ethics. Some scholars, concerned with this area, examine how it is possible to construct one's subjectivity differentially, even within organizational and institutional contexts that demand sameness and homogeneity (e.g. ten Bos, 2003). Others consider the problem of how to engage with the difference of the others that one encounters at work (e.g. Jones, 2003). Authors have embarked on a number of theoretical avenues in order to explore these questions, drawing for example on the work of Jacques Lacan (Jones and Spicer, 2005), Michel Foucault (Chan and Garrick, 2002) and Emmanuel Lévinas (Jones, 2003; Rhodes, 2009). All share a concern with what Rhodes and Wray Bliss term an 'ethics of difference' (2013: 43), whether this refers to processes of subjective identification in the context of contemporary organization, or to the issue of engagement with the 'strange other'.

While providing a number of insightful contributions, some problems and questions remain within such critical approaches to the topic of organizational ethics. These specifically relate to how the body is theorized in organization studies, omitting affect or even the sexuatedness of discourse as an embodied practice (Fotaki, Metcalfe and Harding, 2014). Such issues are however foundational to feminist ethics, where they have been explored from a variety of angles. Feminist ethics is an area that, until recently, has been almost totally overlooked in organization and management studies literature, with some notable exceptions (Ferguson, 1996; Calás and Smircich, 1992; Brewis, 1998; Wray-Bliss, 2003; Collins and Wray-Bliss, 2005; Jones and ten Bos, 2007). Emerging new works have begun to address this omission by drawing explicitly 
on neglected feminist theories. These include Heather Höpfl's engagement with Julia Kristeva's work to theorize a different ethics for organization based on the concept of the maternal (Höpfl, 2000; Höpfl and Kostera, 2003), and Phillips and Rippin's (2010) use of Kristeva's ideas on the abjection of the female body to analyze the development of Starbucks' company's image. The ethics of embodiment discussed in the work of French post-structuralist feminist writers and their implications for organizations served as an inspiration for Fotaki's empirical work on the absence of women from top jobs in management and business schools in England (Fotaki, 2010; 2013), while Kenny (2010a, 2012) drew on the work of Judith Butler to explore the dark side of passionate attachments to an ethical organization. Recently, Phillips, Pullen and Rhodes (2013) have utilized Hélène Cixous' idea of a 'masculine libidinal economy' to disrupt the dominant mode of writing in organization studies, proposing a bisexual writing in its stead and thus forwarding debates on the ethics of writing (Rhodes, 2009). Despite such notable exceptions, the utilization of feminist theorists for developing approaches to ethics within management and organization theory remains in its infancy.

In this paper, we aim to further this work, by drawing on feminist contributions to theorize an ethics of difference from an embodied perspective. Specifically, we take up the challenge proposed in recent debates on corporeal ethics within organization studies (Pullen and Rhodes, 2010), and extend existing theoretical perspectives to encompass Bracha Ettinger's ideas on matrixial trans-subjectivity (2006a). As we shall show, the matrixial that encompasses connectivity, inclusivity and compassion, presents us with a new ethical proposition for organizations as it invokes the idea of co-habitation and joint relational space. Ettinger emphasizes the corporeal, embodied nature of the 
matrixial (as related to the womb) denoting that 'I' is always inextricably linked to the unknown non-I or the Other/ (m)other. In this way, her work provides a fruitful new direction for corporeal ethics, an emergent approach within organization theory that was first proposed by Pullen and Rhodes $(2010 ; 2013)$ in their adaptation of the work on corporeal ethics by Rosalind Diprose. Corporeal ethics specifically focuses upon the politically-engaged affective body that responds openly to others without always having to consider the self.

Our paper progresses as follows. First, we position our contribution by reviewing existing work on ethics, embodiment and materiality in organizations. We then ground Ettinger's ideas with reference to the work of Luce Irigaray, Hèléne Cixous and Julia Kristeva, as she is considered their disciplinary successor, before detailing the relevance of her thinking for our study. We also make reference to Judith Butler's oeuvre since Ettinger's preoccupation with the vulnerability of life further develops aspects of Butler's later work. We illustrate these ideas with examples from studies of gender in the workplace. The paper concludes by outlining multiple implications of this approach for rethinking questions of difference, and gender, in the context of corporeal organizational ethics.

\section{Ethics and difference in organization studies}

Before describing the relevance of Ettinger's work, it is important to examine in more depth existing theoretical approaches to corporeal ethics and how these relate to organizational ethics. As noted above, the ethics of difference and otherness are key ideas within current perspectives. The question that connects these varying perspectives 
is how we can 'live (and work) together in a world beset by difference?' (Rhodes and Wray Bliss, 2013: 40). This deals with the issue of whether ethics is possible in contexts, such as workplaces, in which difference between subjects necessarily prevails (ten Bos, 2003). Scholars have examined the ways in which ethical subjectivities emerge as subjects enact these differences (see Rhodes and Wray-Bliss, 2013: 46-47), and have adopted a number of perspectives to do so. In what follows, we outline three.

\section{Foucault and ethical subjectivity}

Foucault's work shows us how people come to identify with, and be subjected to, different dominant discourses (Chan and Garrick, 2002; Rhodes and Wray-Bliss, 2013: 43). Although Foucault has not directly dealt with issues of gender, his ideas have been influential in understanding how discourses of gender operate (Thomas and Davies, 2005). Many have drawn on the Foucauldian notion that implicitly gendered discourses proliferate in organizations, and encourage the production of docile, self-disciplining bodies (Trethewey, 1999; Holmer- Nadesan and Trethewey, 2000). Among other insights, such studies share an attention to gendered forms of power, and how these operate to discipline working women through their bodily performances. While not explicitly articulated in terms of ethics, feminist organization scholars have highlighted the ways in which particular discourses or 'scripts' subjectify both males and females by offering an ideal embodied identity for which one must strive (Holmer-Nadesan and Trethewey, 2000: 224). Swan (2005) examines how the teacher's body is a surface upon which competencies and abilities are inscribed, often in hierarchical ways, while Gatrell (2011) takes this work further by showing how the maternal body is a text that is inevitably positioned outside organizational practices. 
In recent years, scholars adopting a Foucauldian view of subjectivity have countered earlier criticisms of an 'absent subject' (see Newton, 1995; Mumby, 2005), and described the varied ways in which subjects respond to dominant discourses by adopting, resisting and subverting multiple positions (Knights, 2002; Knights and McCabe, 2000; Skinner, 2013). Even so, commentators have continuously pointed to a lack of theorization at the level of the subject, on the question of how and why such identification takes place (Bardon and Josserand, 2011; Collinson, 2003).

In response, organizational scholars have introduced the idea that the subject engages with discourse, not via abstract social structures, but in a relational way (Alvesson, Ashcraft and Thomas, 2008), that is, through identification with other subjects: other 'networks' (Foucault, 1990: 94-95). A second pre-occupation within this body of work has been to see identification and subjectification as always 'becoming', always in process (Hancock and Tyler, 2001; Ybema et al., 2009) although again, further theorization of this concept is called for.

\section{Psychoanalysis, subjectivity and patriarchy}

As a second approach to furthering our understanding of subjectification to discourse, scholars have drawn upon Lacan's ideas on desire and identification (Jones and Spicer, 2005; Stavrakakis, 2008). Studies that take theoretical inspiration from Judith Butler's work on the psychic mechanisms of subjection (1997) to explain how people develop passionate attachments to norms and values that may harm them, provide other useful examples (see Kenny, 2010a, 2012; Roberts, 2005). What such studies show us, is that the psyche must not be overlooked in considerations of how people come to be subjected to, and position themselves in relation to, forms of power and authority in 
society. These insights have important implications for an organizational ethics of difference (see Rhodes and Wray Bliss, 2013).

Even so, it can be argued that such an approach risks reinforcing gendered flows of power. Commentators have pointed to a legacy of sexism within psychoanalytic social theory, and note the problems that can be inherited when inherently phallo-centric theoretical approaches are used to study organizations (Fotaki, 2010; Kenny, 2009). Fotaki and Harding (2013) for example summarize feminist readings of Lacan's Seminar XX on sexuality and propose an alternative analysis of his work. They put forward an argument for conceptual bisexuality as a new politics of gender in organizations and point out the comic and precarious phallic symbols upon which paramount claims to power, authority and knowledge are being made, in their endeavour to disrupt dominant organizational discourses. Rather than diagnosing desire and lack in others, the authors suggest, it may become possible for scholars to explore their own passions, lack and fallibility and through such elaborations seek to bring about changes in the symbolic. Despite such exceptions, a patriarchal legacy persists in many psychoanalytic studies of organization.

\section{Embodiment and power}

A third theoretical perspective of note has been the one proposed by Pullen and Rhodes (2010) that highlights the role of embodiment within organizational ethics. Noting an absence of the body in existing understandings, the authors draw on Lévinas to explore the issue of embodiment and embodied subjects. They suggest that gendered positions are imposed upon people in contemporary workplaces, and use the analogy of a mask to 
describe the embodied nature of this process. Pullen and Rhodes point out that the forcing of gendered masks onto subjects effectively prevents any opportunity for an ethical relation to develop (2010: 234). This is because such masks cover the body and remove the possibility for a face-to-face encounter that forms the bedrock of an ethical relation. Having detailed this problem, the authors call for scholars to explore new ways of theorizing the removal or lessening of such gendered masks by drawing on Rosalind Diprose's (2002) notion of inter-corporeal generosity. In so doing they propose new ways of understanding the intersection between power and affectivity in the context of organizational ethics and its relation to gender. As Pullen and Rhodes (2013:7) elucidate, corporeal generosity 'stems from an understanding of bodily practice that precedes rationality and intellect (and hence precedes also organization) in an affective dimension where bodies move and respond to other bodies whilst recognizing them as unassimilable'. Pullen and Rhodes' account of an ethics of hospitality and generosity that might inform everyday organizational practice and life more generally, resonates with ideas of co-habitation, inclusivity and sharing through the embodied matrixial borderspace proposed by Bracha Ettinger, as will be discussed next.

In summary, a number of approaches to an 'ethics of difference' have emerged within organization studies. Some explore the possibility of an ethical engagement with others, even in the face of differences, yet others examine the discursive and subjective reproduction of such difference. What all of these studies share is an implicit engagement with questions of difference and otherness as important concepts in understanding organizational ethics. However, there remain some issues and problems upon which this paper aims to shed light. These are described below. 
First, the materiality of the body tends to be omitted from such discussions. With the exception of recent works as described earlier (Hancock and Tyler, 2000; Pullen and Rhodes, 2010; 2013), there is a tendency to view the body only as something that is discursively constructed. Even recent studies in which the material body is 'brought back in' (Ashcraft, Kuhn and Cooren, 2009; Orlikowski and Scott, 2008), tend to focus upon the techno-administrative use of bodies in organizations that are a product of discourse, rather than with what Grosz calls a 'lived body' (Styhre, 2004: 102). The materiality of the body thus remains absent. Furthermore, with male bodies representing relations of power and domination in discourse, the male subject often becomes the explicit or implicit focus of organizational theorizing. The sexuatedness of language is also omitted from such analyses (Fotaki, Metcalfe and Harding, 2014).

Second, despite a turn to the relationality of the subject, theoretical approaches to the subject's engagement with difference remain lacking within organization studies. Overall, the logic of domination and submission underscores contemporary understandings of the way the subject relates to the other. This is inspired by Hegel's Phenomenology of the Spirit and its well-known account of relational subjectivity (Hancock and Tyler, 2001). Commentators argue that this is a legacy inherited from a particular reading of Hegel's master-slave dialectic by Kojève, an author that influenced Foucault and Lacan among others (Butler, 1999; Osborne, 2010). Kojève focused on the way in which, in the Phenomenology, the two consciousnesses that encounter each other are locked in a battle 'to the death'. The development of subjectivity therefore depends on an Other, but results either in the annihilation of the other by the self, or vice versa. 
This legacy persists in contemporary post-structuralist understandings of relationality (Benjamin, 1988), not least the Foucauldian approaches that have of late been so influential in organization studies (Kenny and Harding, forthcoming). This version of relationality that is founded on domination and submission has, in our view, lead to an emphasis on negative aspects of the ethical construction of subjectivity. We are thus left with limited possibilities for theorizing ethical subjectivity and how it might develop (Rhodes and Wray Bliss, 2013: 42).

Third, although approaches have to date drawn on a varied and eclectic range of sources, the absence of the feminine persists within even the critical study of business ethics, with the exception of studies that reference the 'ethics of care' approach (see Derry, 2002). Overall, there is a lack of empirical attention to issues of gender and sexuality within the field of business ethics (Dunne, Harney and Parker, 2008: 273), a theoretical unwillingness to engage with feminist writers and philosophers despite the fact that this group has long engaged with questions of ethics (Rhodes and Wray Bliss, 2013: 48), and an inherent sexism within theoretical approaches, for example psychoanalytic ones that emphasize the centrality of the phallus (Fotaki, 2011; 2013; Fotaki and Harding 2013; Kenny, 2009). In this paper, we continue the project at hand and ask how we might deepen our understanding of an organizational ethics of difference that engages with feminine corporeality, in order to develop new ethical concepts of resistance. We begin this by introducing Bracha Ettinger's work. 


\section{Bracha Ettinger and ethics}

\section{Background}

Despite some relatively brief but provocative mentions (Fotaki, Long and Schwartz, 2012), Ettinger's work has not yet been drawn upon in management and organization theory. In this, she joins with other female feminist writers whose ideas remain all but unknown. As noted above, there has of late been a shift in attitude with scholars drawing increasingly on work by Beauvoir, Kristeva, Cixous, Butler and Irigaray (Fotaki, 2010, 2013; Höpfl, 2000; Höpfl and Kostera, 2003; Kenny 2010a, 2012; Marshall, 2000; Phillips, Pullen and Rhodes, 2013; Phillips and Rippin, 2010; Vachhani, 2012), although too often the influence of these ideas remains at the periphery of organizational research.

This paper intends to further such work by drawing on the psychoanalytic, philosophical, feminist and aesthetic ideas of Bracha Ettinger, which position embodied ethics at its centre. In addition to creative exchanges with Butler, whose ideas clearly inform her work, Ettinger's oeuvre also reflects wider influences from feminism, postmodern philosophy, and more specifically and uniquely, insights from painting and post-Shoah modernity (Pollock, 1995). She engages with and speaks to French poststructuralist psychoanalysts including Luce Irigaray, Hèléne Cixous ${ }^{1}$ and Julia Kristeva, building upon their ideas as well as those of Freud, Lacan, Lévinas, Merleau-Ponty and Lyotard amongst others (Giffney, Mulhall and O’Rourke, 2009), in order to develop a

\footnotetext{
${ }^{1}$ In her artistic creativity she is closer to Cixous although Ettinger chooses visual means rather than theatre as a channel for expressing her philosophical ideas. As Griselda Pollock, an arts critic and academic puts it, the philosophy of the matrixial was developed by Ettinger through her own artistic practice: 'Across these borderlines of those of painter and painting, the possibility of another stratum of subjectivity and subjectivization was glimpsed' (Pollock, 1995:130).
} 
post-phallic theorization of subjectivity. Like Irigaray (1985a, b) and Kristeva (1982, 1991) she is preoccupied with the female body as the site of pre-symbolic signification.

However, Ettinger departs from these thinkers in some respects. For example, unlike Irigaray she does not propose the womb as contrast to male phallic signifiers but rather offers her conception of the matrixial borderspace as a site of connectivity between male and female. Ettinger's proposition of the matrixial borderspace as a symbol and joint space in which its mutually unknown elements encounter each other without merging or repelling, offers an alternative supplement to predominant conceptions of the formation of human subjectivity (Pollock, 1995), including those described above.

Ettinger's ideas and resulting conceptual devices, discussed in more detail below, have potential implications for re-theorizing corporeal organizational ethics by focusing on its various constitutive parts such as body and gender identity. A key inspiration is her concept of the compassionate and inclusive matrixial as an ethical proposition for rethinking embodied difference and otherness in organizations. We now turn to examine specific ideas and conceptual developments within Bracha Ettinger's work concerning (a) the other as within; (b) co-emergence; (c) relational space; and (d) compassion.

\section{Key concepts}

a) the other as within

A psychoanalyst, clinical psychologist, artist and philosopher, Ettinger argues, among other things, that the maternal has been largely overlooked as a fruitful lens by which 
we might view relations between subjects. This is a mistake, she proposes, as much can be learned about how we engage with others by focusing on relations between the caring adult and the infant. For Ettinger, the maternal is key. She builds on the concept of Kristevan 'herethics' as a model of outlaw ethics, founded in the ambiguity inherent to pregnancy and birth, surrounding that which exists between subject position (the mother as being located in the symbolic) and object position (the mother as connected to nature) (Oliver, 1993:6). Developing this, Ettinger proposes a concept of the matrixial borderspace that comes to represent that which is 'in-between' mother and baby; this space is material as well as symbolic. Maternal subjectivity is an experience involving a 'feminine-matrixial connectivity' that depends upon, and fuels, particular experiences of affective encounters with an other (Ettinger, 2010: 1). In such encounters, the other in question becomes specific, and the subject is compelled to do what it can to care for it. Ettinger describes a primal affective impulse, or 'fascinance and awe' that arises here, and argues that the emergence of this affect counters the psychic, and psychoanalytically-theorized, tendencies towards abjection described for example by Kristeva (1982).

The experience relies upon an opening up of the self, or 'self-fragilization', in which the 'boundaries of the subject (are opened) to transubjective inspirations' (Ettinger, 2010: 6). This 'fragilizing' process, denoting the experience of becoming open, 'fragile' and therefore vulnerable, is central to enabling an encounter with the other that does not attempt to dominate and oppress them, as might otherwise occur: it is 'precisely the self-fragilizing transubject that can contact the vulnerability in the other without retraumatizing (him or her)' (Ettinger, 2010: 6). This encounter therefore taps into and 
relates to 'plural, partial and shared unconscious, trauma, fantasy and desire' (Ettinger, 2006a: 64), a final departure from the concept of the autonomous, detached subject. In this way, Ettinger's work resonates with post-modern, feminist and psychoanalytical theory, including for example Butler's (2004) critique of the notion of an autonomous subject with no relational needs. For Butler, such a conception is a fallacy whose promulgation threatens social bonds, promoting a form of false individuality that is governed by denial and destruction (Butler, 2004). In her recent work with Athena Athanasiou (2013), she calls for a re-theorization of subjectivity in which the conception of the self 'does not refer to an autological and self-contained individuality, but rather to responsive dispositions of becoming-one-with-another' (Butler and Athanasiou, 2013:73).

Ettinger's contribution here is to develop such accounts of subjectivity yet further. Not only is the subject for Ettinger 'not separate', but neither can it be precisely represented other than: 'at the very limits of conscious/unconscious, of an awareness of what is already there' (Pollock, 1995: 134) and as encounter with another through an affective experience. The aesthetic experience of her art practice informs how she perceives awareness between subject and other. This approach 'allows recognition of a subjectivity experienced at the very limits of the visible, which is not premised on a masculine gaze and its objects, but in an encounter at a threshold which creates what she calls a "borderline awareness"" (ibid.). 
The concept of the matrixial proposed by Ettinger has implications for organization studies and more specifically for the re-theorization of organizational ethics, as described in the concluding section of this paper.

\section{b) co-emergence}

Since the matrixial is not in opposition to the phallic but is rather coexistent and in complementary relation to it, it allows us to think of subjectivity outside of binaries that signify relationships of 'either or', or 'the one as opposed to the other', and in which the subject finds itself devoid of sociality. Instead we are given a conceptual apparatus to consider the subject in relation to another that is different from the self, as called for by others (Butler, 2004). Ettinger again takes this work further by proposing a (psycho-) somatic basis of subjectivity that ably navigates both the dangers of being subsumed by the other, and of occupying a space of absolute difference that is achieved at the risk of unintelligibility. This makes possible the ethical relation between a subject and the 'different' other it encounters, which is a central concern of this paper.

Elaborating on the ethical relation implied in this matrixial position, Ettinger notes that rather than involving a struggle against an 'outside instance', in contrast it begins with a struggle against one's own 'narcissistic self', a process that can only be attempted through 'self-fragilization', opening up the self generously toward the other, inspired by the affects emerging from the matrixial encounter. Ettinger describes this as 'an enigmatic call: the Hineni: "here I am" without the aiecha: "where are you?": a nonsacrificial modus of response (Ettinger, 2010:19). This joint space is best captured by a metaphor of the intrauterine life, hence the term 'matrixial borderspace'. Importantly, 
while the matrixial symbolizes the maternal encounter, at the same time it exceeds it. The 'nonconscious matrixial stratum of subjectivization' she describes is not specific to women (ibid. 63). As Lyotard (1995: 28) puts it when describing Ettinger's work: 'I would say that if there is a feminine - and a feminine there is - it does not allow the line of the division of the sexes' (italics in the original). Such a division is, paradoxically, antithetical to the concept of the matrixial. In other words Ettinger convinces us that the ' $\mathrm{I}$ ' is never complete without the 'other' that the 'I' discerns as 'non-I'. Even without knowing each other; they co-emerge and cohabit a joint space with fusion and without rejection (Ettinger, 2006a, p. 65).

\section{c) Relational space}

Ettinger restitutes the womb at the symbolic and imaginary level by equating it with life-giving rather than death. Thus she rethinks the common association of the womb with the intra-uterine enclosure and the site of the unheimlich (the uncanny) present in the works of the fathers of psychoanalysis namely, Freud and Lacan (see Kristeva's, 1991, discussion of the uncanny in Freud, 1919). But her intention is not to antagonize Freud or Lacan by exposing and counteracting their arguments. This would merely lead to an inverse logic of confirming the position of the feminine as a negative non-phallus (with phallus being the positive). Her aim is rather to introduce the matrixial as an encompassing parallel to the phallic universe, as a second consciousness-determining structure (Shail, 2007). In the words of Griselda Pollock in the preface to her major oeuvre: 'the matrixial surfs beneath/beside the phallic' (Pollock in Ettinger, 2006a: 6) thus offering a 'different subjectivizing stratum to the phallus' (Ettinger, 2006a: 48). 
For Pollock 'the matrix' is that which: 'poses and opposes the I to the other in a variety of constitutive relations of difference leading to paradigms of exclusion or assimilation, love or hate, incorporation or rejection, presence or absence' (Pollock, 1995: 131). The quality of the matrixial is therefore that it accounts for co-dependence and offers a space for linking, making relations and 'being with' the unknown other possible. Such an approach, as Butler explained almost two decades ago, has powerful implications, evoking identifications that are 'ambiguous and cross-corporeal cohabitations' (1993:105). For Butler, alterity can be present in any conception of 'I' and can therefore unsettle it. If the subject can come to accept this "sedimentation of the "we" in the constitution of (his or her) "I", it can offer an opportunity for a liveable life where this may previously have been denied (see Kenny 2010a, 2012). This offers an alternative to self-beratement and self-abjection.

Rather than radically departing from Butler's aim, Ettinger thus provides a conceptual foundation for developing aspects of her thought. This she achieves by grounding her theorizing in her experiential understanding of the workings of the psyche, both as an artist and a practising psychoanalyst, as she engages with and works through the painful history of her European Jewish heritage. Ettinger (1993:84-85) describes how, 'as a child I was a witness to witnesses. When I paint or when I listen I am that too'. Ettinger's relationality therefore is not merely symbolic but also visceral since for her the one does not exist without the traces of the other. Further, in relationality, individual subjectivity is reaffirmed through an interdependency that makes care relations possible. This may lay the psychic foundations for an ethical stance of hospitality and compassion for 'the other in their otherness' (Pollock, 2008: 10). 


\section{d) Compassion}

For Ettinger, the affects emerging from the matrixial relation act to counter-balance impulses of aggression and exclusion: 'compassion and awe balance disgust, rage, jealousy and envy, and also fear. Fascinance balances distrust' (Ettinger, 2010: 19). Compassion is inextricably interwoven with and suffuses the matrixial. As Ettinger (2010: 1) puts it: 'the infant meets the maternal subject via its own primary affective compassion. I view the effect of primary compassion as a primal psychic access to the other. It arises before, after and also alongside abjection'. Compassion signals contact and connection with the other but also the self: 'the compassion and respect toward the intimate non-I(s)... unconsciously nourishes the transubjective dimension of the individual subject and revives their primary compassion and awe' (2010: 3). The compassion that Ettinger describes as a primitive beauty, counteracts fragility, trauma and death, by expressing the desire, life and passion associated with the matrixial (ibid.). In the analytic relation, the emergence of these affects can help to contain destructive feelings, which can also be extended into the social. Hence, Ettinger argues, a matrixial-inspired sense of compassion and awe can engender what she terms 'protoethical paths to freedom-with-resistance', that is, a resistance 'impregnated by and built upon compassion, awe and fascinance', which is fundamentally different to one that is ‘impregnated by fear, disgust and rage' (Ettinger, 2010:19).

In summary, the ability to connect with the child in 'bare life' has significance for intersubjective engagement. Herein lies its ethical potential; intersubjectivity is viewed as an encounter that takes place at 'shared borderspaces' between subjects that are only ever partial in and of themselves, and ultimately unknown to each other. As Pollock 
notes, these 'strange, foreign, irreducible elements of otherness' that mark our encounters promise a rethinking of ethical relations (Pollock, 2004: 7).

Ettinger's theorization of human subjectivity presents us with a novel understanding of gender and sexuality as always connected to the maternal (female, care- and life-giving) via the matrixial borderspace. Returning to organization studies, Ettinger's ideas resonate with other scholars who have for example drawn upon Kristeva's idea of abjection to understand the work of organizations (Höpfl, 2000; Phillips and Rippin, 2010), and Irigaray's work on woman's absence in thinking about the representation of femaleness in discourses of leadership within management textbooks (see Oseen 1997, Kenny and Bell, 2011), and in organization theory (Vachhani, 2012; Fotaki, 2013). In the context of this paper, the experience of the maternal-matrixial adds to current understandings of the ethics of difference. In particular, the ideas presented here have powerful implications for the aims of this paper; considered together, the body, the feminine and otherness offer the potential to develop an inter-corporeal ethics of organization. We next describe this potential in detail.

\section{Implications of Ettinger's work for organizational ethics}

We propose a lens for organization studies that draws on Bracha Ettinger's work on intersubjectivity as we develop a theory of inter-corporeal organizational ethics. In so doing we build upon the idea of inter-corporeal generosity developed by Diprose (see Pullen and Rhodes, 2010). Diprose describes an ethics that originates from an emergent and affective experience with others that precedes and exceeds those rational schemes that seek to regulate it. It is an experience that welcomes other peoples' differences as it 
emerges from embodied experience, that is pre-reflexive in origin and socio-political in practice (Pullen and Rhodes, 2010). Ettinger's ideas can take this work yet further as she links body with the psyche, the conscious with the unconscious, presence with an absence and positions the feminine alongside the phallic. She achieves this through her language of the matrixial (that Pollock has aptly described as the écriture matrixiale see Pollock, 1995: 130), which tries to capture what is behind the image and representation.

Importantly, for Ettinger the experience of the maternal-matrixial is not limited to the parent-infant encounter. While the subject loses the memory of this as time passes, its traces remain inscribed within the psyche. They contain the potential to 'nourish the I' throughout the subject's life (Ettinger, 2010:3) and have important implications for understandings of ethics in the social (Pollock, 2008) and organizational ethics particularly (Harding et al., 2013: 59). In particular, it addresses three notable lacunae within existing approaches to organizational ethics described earlier, to do with the absence of the body, the negation of the feminine and the need for a theorization of subjectivity that is not solely based on domination.

\section{The body}

Ettinger's ethics are firmly located within the body. Her focus is not on the opposition between, but rather the embodied co-existence of the subject in togetherness with, an other. She proposes the idea of the matrixial not merely as a symbolic device but also as material practice that connects us to others, irrespective of their anatomy and 
identification as female, male or otherwise. In place of the autonomy that a singular idea of (phallic) subjectivity denotes, Ettinger offers linkages.

First, while women are seen as having a privileged access to the matrixial because of their closer relation to the maternal, irrespective of whether they have children themselves, the matrix represents an invisible structure that exceeds the specificity of the feminine body that it symbolizes. It is rather created as a stratum of connectivity that allows for intersubjective encounters, and for hosting other subjectivities. This proves to be critically important for political and ethical reflections on relations with the other, the stranger, and the unknown: in short, for all that represents difference. In other words, the matrixial proposes a different conception of subjectivity that contrasts with the phallic model, where the feminine is seen as the other of masculinity but is not intended to replace it.

Second, through highlighting the limitations to traditional ideas of the autonomous selfsufficiency of the subject, her work has wider political implications not least for contemporary organizations. Specifically, it puts into question the neoliberal project that assumes the existence of an impermeable individualized subject, by bringing in the idea of human connectivity and injuriousness. In so doing it establishes the subject as a relational and interdependent being. While the importance of relationality and interdependence has been argued by critically-minded organizational scholars before (Collinson, 2002; Knights and Willmott, 1989), what is different here is that Ettinger 
offers more than a notional and theoretical position and provides an account of relationality that originates in the human body.

This 'corporeal' insight has important implications for organizational ethics. Drawing on Judith Butler's concept of the precariousness of human lives (2009), an ethical engagement is inescapably embodied; it is the acknowledgement of the 'injurability' of our finite human bodies, and hence our shared experience of 'precarity' (both neologisms coined by her) as embodied humans, that enable us to be affected by the vulnerability of others. In Frames of War (Butler, 2009) for instance, she specifically discusses recent justifications of the war on terror. Butler is preoccupied with questions of what makes certain lives liveable and worth grieving; she concedes that there can be no differential distribution of precariousness and grievability over any lives lost, because it is our fear but also our possibility of survivability that links us to the others we do not know (see also Kenny 2010b for a further discussion). Our literal survivability is thereby linked to the survivability of the other (Butler, 2009).

Ettinger's work can help us to understand how this is achieved through bodily hurt of the other and the annihilation of the (female) body in extreme cases. This stems from the influence of Holocaust memories and the experience of working through the resultant grief on her thinking, both of which place bodily vulnerability and the ways it defines us as relational beings, at its centre. She moves away from the abstract level of disembodied ethical injunction and develops a model of ethical response as an affective mode of being, which is felt in/through the body. In this way materiality and 
corporeality are foundational aspects of her theorizing since, as she puts it: 'we must return to the body because the body can be killed' (Ettinger, 2012, personal communication).

Ettinger therefore departs from the Lévinasian call for abstract responsiveness towards the other, offering a perspective that sees our responsibility for the other as deeply embodied, since the other already co-habits and co-exists with the I. In this way, by proposing the notion of the compassionate matrixial she reconsiders the concept of the other as trauma to the self. Ettinger thus takes the question of precarious relationality further by elevating it to an ethical position as she demonstrates that there is no subjectivity without relationality and no relationality without the other. In other words, her idea of the subject co-emerging as part-subjects through the encounter with an unknown other presents us with a compelling ethical proposition that stems from the feminist position of being attuned to 'becoming together'; it is the fact that human lives are mutually and already implicated in one another that establishes the principle of equality and connectedness.

Moreover, given this embodied proximity of self to non-self, Ettinger's is an encounter that calls for a specific action. In relation to emergent organization studies debates on inter-corporeality outlined above, what this perspective can offer is a deeper theorization of such a position, encompassing the sharing of embodied space, experiences of trauma and affect between subjects, along with the memory traces of this legacy that persist. Brought together, these can offer a thorough conceptualization of 
shared borderspace that gives us a language by which we can better understand experiences of inter-corporeality. The return to the body via the matrixial therefore has powerful implications for theorizing organizations and organizing.

Third and final, in this way, Ettinger's work contributes to emergent work on the complexities of the body in organizational spaces. It relates to influential debates in organizational studies (Hassard, Holliday and Willmott, 2000; Brewis and Linstead, 2003; Swan, 2005), by linking the body to the articulation of an ethical position for organizational practice. In terms of organizational ethics, we can see that the proposed approach addresses the problematic absence of a material account of the body that has to date persisted. A focus on the vulnerability of the embodied subject can help us to understand how particular subjects can be hurt; Ettinger's work yields fruitful insights into the hurt and pain that can be inflicted, for example when priority and privilege is bestowed upon certain embodied subject positions and denied to others, and when subjection is demanded as a part of one's working life (Harding et al., 2013: 59-60). These insights are also relevant in the context of embodied, affective labour that is ever more a reality in organizations in the twenty-first century.

\section{Ethics and Difference}

In considering potential theoretical avenues for exploring organizational ethics and the question of difference, Ettinger's work offers the potential to build upon existing approaches described above, including Foucauldian and Lacanian accounts, by offering a deeper theorization of the relational aspect of subjectivity. Here, Ettinger's work provides valuable insights; her concept of the matrixial offers an account of an 'in- 
between' space, in which subjects co-emerge and constitute one another. Consciousness is therefore 'plural and shared' (Ettinger, 2006a: 64), but its development does not involve the annihilation of one by the other. Importantly, this is not a vision of a utopian future in which affects such as disgust, hate and abjection have been abolished. Rather, such human experiences are seen to co-exist with, though not necessarily dominate, affects like fascinance and awe that fuel a deeper understanding of the human condition. Overall, this resonates with and builds upon recent work in organization studies that aims to highlight the ways in which subjectivity is a process of becoming, rather than a static 'event' (Hancock and Tyler, 2001; Harding, 2007; Ybema et al. 2009: 301).

This account provides a deeper understanding of difference within inter-subjective encounters, which can contribute to the development of an organizational ethics of difference as described above; it speaks directly to the key issue of "consensus within difference' within this body of work. Rhodes and Wray-Bliss (2013) point to a gap in existing understandings of this problematic, calling for further work that addresses the central, albeit paradoxical question for organizational studies, of 'how we live (and work) together in a world beset by difference?' (Rhodes and Wray-Bliss, 2013: 40). Despite some focus on an ethics of consensus within organization studies, including an engagement with ideas of dialogue and 'being with' another subject, there exist few studies on these issues. Even fewer have considered how this approach might intersect with an ethics of difference: that is, how an ethical approach might be developed that incorporates both sides, where differences are bridged in order for mutual respect and a genuine engagement with the other to emerge. Here, Ettinger's nuanced theorization of matrixial co-emergence can enhance such understandings. In particular however, 
Ettinger's account of relationality proposes a new direction for theories of subjectivity, one that moves beyond the post-structuralist interpretation of Hegel's Master/ Slave dialectic. In place of an emphasis on domination, Ettinger offers a nuanced account of a matrixial that is suffused with particular affects of 'fascinance and awe' yielding a sense of involvement and ethical responsibility.

\section{On gender: addressing the 'feminine as blind-spot'}

Furthermore, Ettinger's ideas have implications for theorizing corporeal ethics in the context of organizational gender relations. As others have long argued, contemporary organizations are often founded on deeply gendered substructures (Acker, 1990). Within such contexts, differences between male and female can be highlighted and reinforced through various organizational practices. The female body can therefore become stigmatized, seen as 'other' to the masculine norm and defined for example as inherently sexual, volatile and disruptive (Burrell, 1992; Sheppard, 1989; Trethewey, 1999). There is in other words an amplification of difference between gender positions. What the matrixial's embodied, co-emerging account of subjectivity can offer is a problematization of such separation and difference, and an attention to the ethical impulse that results. This implies new ways of understanding differential, gendered, subject positions within contemporary organizations. In relation to gender, Ettinger also breaks with both the Freudian-Lacanian paradigm and the intersubjective as a field of communication, in her rethinking desire and the unconscious through the matrixial borderspace. Specifically, she contrasts her concept of the woman-as-feminine from others such as Lévinas and Lacan in parts of his work, who perceive it as a necessarily sacrificial position that is destined for suffering. 
First, Ettinger argues that the reliance of psychoanalytic theory on the Freudian concept of the unconscious results in limited understandings of the formation of subjectivity. This reliance privileges the phallus as 'the' signifier of the dynamic between lack and desire, supporting a model of repression that is based on the castration complex (Ettinger, 2006b: 218). This 'male' perspective highlights how aggression and sexuality are repressed in contemporary society and should be reinstated and brought to the fore, for example in analysis. For Ettinger, affects such as 'compassion, awe and fascinance' that are, in fact, silenced and denied have lead to the denigration of the maternal position, instilling something of a phallocentric worldview in its place. In order to counteract it, Ettinger proposes a more compassionate intra-subjectivity that incorporates the maternal within the self, and trans-subjectivity as extending beyond individual experience.

A second psychoanalytic assumption contested by Ettinger is the idea that woman stands for absolute Otherness, beyond symbolization. She notes that: 'In Lacan's description, sublimation keeps the woman in a rapport of love at the price of her constitution at the level of the Thing' (Ettinger, 1993:18). In contrast, for Ettinger, in the language of the matrixial, the écriture matrixiale, the feminine-maternal is anchored in the 'connecting potentiality of Eros', that is, the bind of mother to infant. Ettinger continues (1993:18):

...In a matrixial system, the passageway back and forth between exterior and interior, and between Thing and Other, is open and subjectivity situated at the borderlines is not a prisoner of either. The feminine, like painting, can be both 
subject, Other, and Thing or both subject and Other in a constant relation to the Thing (via object a).

Rather than an absence therefore, woman is conceived of as an 'almost-Other' and 'partial-subject', that oscillates between appearance and absence, as a result of such connection. This, she argues, 'infiltrates Ethics' with an idea of a feminine that is primarily grounded in the experience of 'being alive in giving life' (2006a: 101), as opposed to absence and otherness. In short, Ettinger theorizes the ethics of being through the prism of the feminine body and in so doing she overcomes the restricted position of the woman as the untheorizable other, an idea that counteracts the negation of the feminine within organization studies.

Overall, Ettinger dispenses with the notion of the unitary subject, allowing us to challenge the phallic masculinist form of power which effaces sexual difference and difference more generally and thus enacts the mastery over the domain of life. Such a conception is linked to a different affective economy, opening up a non-psychotic relation between the feminine (conceived as neither male nor female) and creativity, that informs knowledge production and ethics.

\section{Conclusion}

In developing a post-phallic theory of the psyche and compassionate relationality through the idea of the matrixial borderspace, Ettinger's ideas enable us to understand organizations in novel ways. 
A matrixial approach in which the political potentiality of affects such as fascinance and awe are given primacy, enables us to re-theorize organizational ethics, and corporeal ethics in particular. This is achieved by developing a theory of subjectivity that moves beyond assumptions of oppositionality and domination. In place, we propose a 'transsubjectivity' that implies the transcendence of subject-object relations, not through a fusion, but through an a-priori shareability in difference. Such a theorization of the subject in relation to the other has powerful political implications for gender and difference in organizations and beyond. It eschews the logic of incorporation of the other and rejects the autonomous individual self as the basis for understanding how we function as social beings:

the subject's relation with the Other does not turn it into an known object, swallowed and fused, rejected or abjected. The non-I as subject changes me while that I changes it; all the participants are receiving and investing libido with-in and with-out the joint process of change itself — the metamorphosis, with-in and with-out their common borderspace. Ettinger (1993: 55):

Ettinger's account of bodily co-habitation that encompasses psychological shareability, proposes exciting new directions for understandings of our sociality. An ethics of organization that is based on the matrixial therefore suggests that a new kind of ethical relation with difference is possible. 


\section{References}

Alvesson, M., Ashcraft, K.L., and Thomas, R. (2008) 'Identity matters: Reflections on the construction of identity scholarship in organization studies', Organization, $15,5-28$.

Ashcraft, K.L., Kuhn, T.R. and Cooren, F. (2009) 'Constitutional Amendments: Materializing Organizational Communication', The Academy of Management Annals 3(1): 1-64.

Bardon, T. and Josserand, E. (2011) 'A Nietzschean Reading of Foucauldian Thinking: Constructing a Project of the Self Within an Ontology of Becoming', Organization 18(4): 497-515.

Benjamin, J. (1988) The Bonds of Love: Psychoanalysis, Feminism, and the Problem of Domination. Pantheon: New York.

Brewis, J. (1998) 'What is Wrong with this Picture? Sex and Gender Relations in Disclosure', in J. Hassard and R. Holliday (eds) Organization-Representation: Work and Organization in Popular Culture, pp. 83-100. London: Sage.

Brewis, J. and Linstead, S. (2003) Sex, Work and Sex Work: Eroticizing Organization. Francis Taylor.

Burrell, G. (1988) 'Modernism, Postmodernism and Organisational analysis 2: The Contribution of Michael Foucault', Organization Studies 9(2): 221-335.

Butler, J. (1999) Subjects of Desire. New York: Columbia University Press.

Butler, J. (2004) Undoing Gender. New York: Routledge.

Butler, J. (2009) Frames of War. New York: Verso. 
Calás, M. and Smircich, L. (1992) Using the 'F' word, feminist theories and the social consequences of organizational research. In: Mills A and Tancred P (eds) Gendering Organizational Analysis. London: Sage.

Chan, A. and Garrick, J. (2002) 'Organization Theory in Turbulent Times: The Traces of Foucault's Ethics', Organization 9(4): 683-701.

Collins, H. and Wray-Bliss, E. (2005) 'Discriminating Ethics', Human Relations 58(6): 799-824.

Collinson, D. (2002) 'Managing Humor', Journal of Management Studies 39(3): 269289.

Collinson, D. (2003) 'Identities and Insecurities: Selves at Work', Organization 10(3): $527-547$.

Derry, R. (2002) 'Feminist theory and business ethics.' In R. Frederick A Companion to Business Ethics. Blackwell Publishing.

Diprose, M. (2002) Corporeal Generosity: On Giving with Nietzsche, Merleau-Ponty and Lévinas. Albany: State University of New York Press.

Dunne, S., Harney, S., and Parker, M. (2008) 'Speaking Out: The Responsibilities of Management Intellectuals: A Survey', Organization 15(2): 271-282.

Ettinger, B. L. (1993) The Matrixial Gaze. Trans. J. Simas, Museum of Modern Art (MOMA). Oxford.

Ettinger, B. L. (2006a) The Matrixial Borderspace (Essays from 1994-1999). Minneapolis: University of Minnesota Press.

Ettinger, B. L. (2006b) 'Matrixial Trans-subjectivity', Theory, Culture \& Society 23: $218-222$. 
Ettinger, B. L. (2010) (M)Other Re-spect: Maternal Subjectivity, the Ready-Made Mother-Monster and the Ethics of Respecting. www.mamsie.bbk.ac.uk/documents/ettinger.pdf

Ettinger, B. L. (2012) Bracha L. Ettinger's Theory of the Matrixial. A public lecture and a clinical conference 23-24 March 2012. Dublin, Ireland.

Ferguson, A. (1996) 'Bridge Identity Politics: An Integrative Feminist Ethics of International Development', Organization 3(4): 571-87.

Fotaki, M. (2010) 'The Sublime Desire for Knowledge (in Academe): Sexuality at Work in Business and Management Schools in England', British Journal of Management 22: 42-53.

Fotaki, M. (2013) 'No Woman is Like a Man (in Academia): The Masculine Symbolic Order and the Unwanted Female Body', Organization Studies 34(9): 1251-1275.

Fotaki, M. and Harding, N. (2012) 'Lacan and Sexual Difference in Organization and Management Theory: Towards a Hysterical Academy?' Organization 20: 153172.

Fotaki, M., Long, S. and Schwartz, H.S. (2012) 'What Can Psychoanalysis Offer Organization Studies Today? Taking Stock of Current Developments and Thinking about Future Directions', Organization Studies 33(9): 1105-1120.

Fotaki, M., Metcalfe, B.D. and Harding, N. (2014) 'Writing Materiality into Management and Organization Studies through and with Luce Irigaray'. DOI:10.1177/0018726713517727.

Foucault, M. (1990) The History of Sexuality. Volume I: An Introduction. Trans. R. Hurley. London: Penguin. 
Freud, S. (1919) 'On the Uncanny' (Das Unheimlich). Standard Edition of the Psychological Work of Sigmund Freud, 24 vols. Vol 17. London: Hogarth.

Gatrell, C. (2011) 'Managing the Maternal Body: A Comprehensive Review and Transdisciplinary Analysis', International Journal of Management Reviews 13(1): $97-112$.

Giffney, N., Mulhall, A. and O’Rourke, M. (2009) 'Seduction into Reading: Bracha L. Ettinger's The Matrixial Borderspace', Studies in the Maternal, 1(2): 1-15. www.mamsie.bbk.ac.uk.

Hancock, P. and Tyler, M. (2000) 'The Look of Love: Gender, Work and the Organization of Aesthetics' in Body and Organization, Hassard, J., Holliday, R. and Willmott, H. (eds), Sage, London.

Hancock, P., and Tyler, M. (2001) 'Managing Subjectivity and the Dialectic of SelfConsciousness: Hegel and Organization Theory', Organization 8(4): 565-586.

Harding, N., Lee, H., Ford, J. and Learmonth, M. (2011) 'Leadership and Charisma: A Desire that Cannot Speak its Name?', Human Relations 64: 927-949.

Hassard, J., Holliday, R. and Willmott, H. (eds) (2000) Body and Organization. Sage: London.

Holmer-Nadesan, M. and Trethewey, A. (2000) 'Crafting the Entrepreneurial Subject: Gendered Strategies of Success(?)', Text and Performance Quarterly 20: 223250.

Höpfl, H. (2000) 'The Suffering Mother and the Miserable Son: Organizing Women and Organizing Women's Writing', Gender, Work \& Organization 7: 98-105.

Höpfl, H. and Kostera, M. (2003) Interpreting the Maternal Organisation. London: Routledge. 
Irigaray, L. (1985a) Speculum of the other woman. Trans. C. Porter and C. Burke. Ithaca, Cornell University Press.

Irigaray, L. (1985b) This Sex Which is Not One. Trans. Gill, G. Ithaca: Cornell University Press.

Jones, C. (2003) 'As If Business Ethics Were Possible, "Within Such Limits"..' Organization 10(2): 223-248.

Jones, C. and Spicer, A. (2005) 'The Sublime Object of Entrepreneurship', Organization 12(2): 223-246.

Jones, C. and ten Bos, R. (2007) Philosophy and Organization. Routledge.

Kenny, K. (2009) 'Heading the Stains: Lacan and Organizational Change', Journal of Organizational Change Management 22: 214-228.

Kenny, K. (2010a) 'Beyond Ourselves: Passion and the Dark Side of Identification in an Ethical Organization', Human Relations, 63: 857-873.

Kenny, K. (2010b) 'Frames of War: When is Life Grievable?', Journal of Power, 3(3): $459-466$.

Kenny, K (2012) "'Someone big and important": Identification and affect in an international development organization', Organization Studies 33(9): 11751194.

Kenny, K., and Bell, E. (2011) 'Representing the Successful Managerial Body'. In E. Jeanes, D. Knights and P. Yancey Martin (Eds.), Handbook of Gender, Work and Organization. Oxford: Blackwell Wiley.

Kenny, K. and Harding, N. (forthcoming, 2015) 'Identity and Philosophy in Organizations: A femini[st]ne blind spot'. In R. Mir, H. Willmott and M. Greenwood (Eds.), Routledge Companion to Philosophy in Organization 
Studies. New York: Routledge.

Knights, D. (2002) 'Writing Organizational Analysis into Foucault', Organization 9(4): 575-93.

Knights, D. and McCabe, D. (2000) “"Ain't Misbehaving”? Opportunities for Resistance under New forms of "Quality" Management', Sociology 34(3): 42136.

Knights, D. and Willmott, H. (1989) 'Power and Subjectivity at Work,' Sociology 23: $535-58$.

Kristeva, J. (1982) Powers of Horror: An Essay on Abjection. (trans.L. Rudiez). New York: Columbia University Press.

Kristeva, J. (1991) Strangers to Ourselves. Trans L. Roudiez. New York: Columbia University Press.

Lyotard, J. F (1995) 'Diffracted Traces' in B. L. Ettinger, Halala-Autistwork. Aix en Provence: Cité du Livre; Jerusalem: The Israel Museum, pp. 6-42.

Marshall, J. (2000) 'Revisiting Simone de Beauvoir: Recognizing Feminist Contributions to Pluralism in Organizational Studies', Journal of Management Inquiry 9(2): 166-172.

Mumby, D. (2005) 'Theorizing Resistance in Organization Studies', Management Communication Quarterly 19(1): 19-44.

Newton, T. (1995) “Managing” Stress: Emotion and Power at Work. London: Sage.

Oliver, K. (1993) Reading Kristeva: Unravelling the Double-Bind. Indiana University Press.

Orlikowski, W.J. and Scott S.V. (2008) 'Sociomateriality: Challenging the separation of technology, work and organization', Academy of Management Annals 2(1): 433- 
474.

Osborne, P. (2010) The Politics of Time: Modernity and Avant-garde. London: Verso.

Phillips, M. and Rippin, A. (2010) 'Howard and the Mermaid: Abjection and the Starbucks' Foundation Memoir', Organization 17: (481-499).

Phillips, M., Pullen, A. and Rhodes, C. (2013) 'Writing Organization as Gendered Practice: Interrupting the Libidinal Economy', Organization Studies. DOI: $10.1177 / 0170840613483656$.

Pollock, G. (1995) 'After the Reapers: Gleaning the Past, the Feminine and Another Future, from the Work of Bracha Lichtenberg Etttinger'. In B. L. Ettinger, Halala-Autistwork. Aix en Provence: Cité du Livre; Jerusalem: The Israel Museum, pp. 129-165.

Pollock, G. (2008) 'Mother Trouble', Studies in the Maternal 1(1). Available at: www.mamsie. bbk.ac.uk/back_issues/issue_one/GriseldaPollock.pdf.

Pullen, A. and Rhodes, C. (2010) Gender, Mask and The Face, in Lewis, P. and Simpson, R. (Eds.) Revealing and Concealing Gender: Issues of visibility in organizations. Basingstoke: Palgrave.

Pullen, A. and Rhodes, C. (2013) 'Corporeal Ethics and the Politics of Resistance in Organizations', Organization. DOI: 10.1177/1350508413484819.

Rhodes, C. (2009) 'After Reflexivity: Ethics, Freedom and the Writing of Organization Studies', Organization Studies 30(6): 653-672.

Rhodes, C. and Wray-Bliss, E. (2013) 'The Ethical Difference of Organization', Organization 20(1): 40-50.

Roberts, J. (2005) 'The power of the "imaginary" in disciplinary processes', Organization 12: 619-642. 
Shail, A. (2007) Book review: Bracha L. Ettinger The Matrixial Borderspace. Forwarded by Judith Butler, Introduction by Griselda Pollock, and with an Afterword by Brian Massumi. Feminist Theory 8: 354-356.

Skinner, D. (2013) 'Foucault, Subjectivity and Ethics: Towards a Self-forming Subject', Organization, 20(6): 904-923.

Stavrakakis, Y. (2008) 'Peripheral Vision. Subjectivity and the Organized Other: Between Symbolic Authority and Fantasmatic Enjoyment', Organization Studies 29: $1037-1059$.

Styhre, A. (2004) 'The (Re)embodied Organization: Four Perspectives on the Body in Organizations', Human Resource Development International 7(1): 101-116.

Swan, E. (2005) 'On Bodies, Rhinestones, and Pleasures: Women Teaching Managers', Management Learning 36: 317-333.

ten Bos, R. (2003) 'Business Ethics, Accounting, and the Fear of Melancholy', Organization 10(2): 267-285.

Thomas, R. and Davies, A. (2005) 'What Have the Feminists Done for Us? Feminist Theory and Organizational Resistance', Organization 12(5): 711-740.

Trethewey, A. (1999) 'Disciplined Bodies: Women's Embodied Identities at Work', Organization Studies 20(3): 423-450.

Vachhani, S. (2012) 'The Subordination of the Feminine? Developing a Critical Feminist Approach to the Psychoanalysis of Organizations', Organization Studies 33(9): 1237-1255.

Wray-Bliss, E. (2003) 'Research Subjects/Research Subjections: Exploring the Ethics and Politics of Critical Research', Organization 10(2): 307-25.

Ybema, S., Keenoy, T., Oswick, C., Beverungen, A., Ellis, N., and Sabelis, I. (2009) 
Kenny and Fotaki (2015), Post-print [final author] version

‘Articulating identities', Human Relations 62: 299-322. 